Provided for non-commercial research and education use. Not for reproduction, distribution or commercial use.

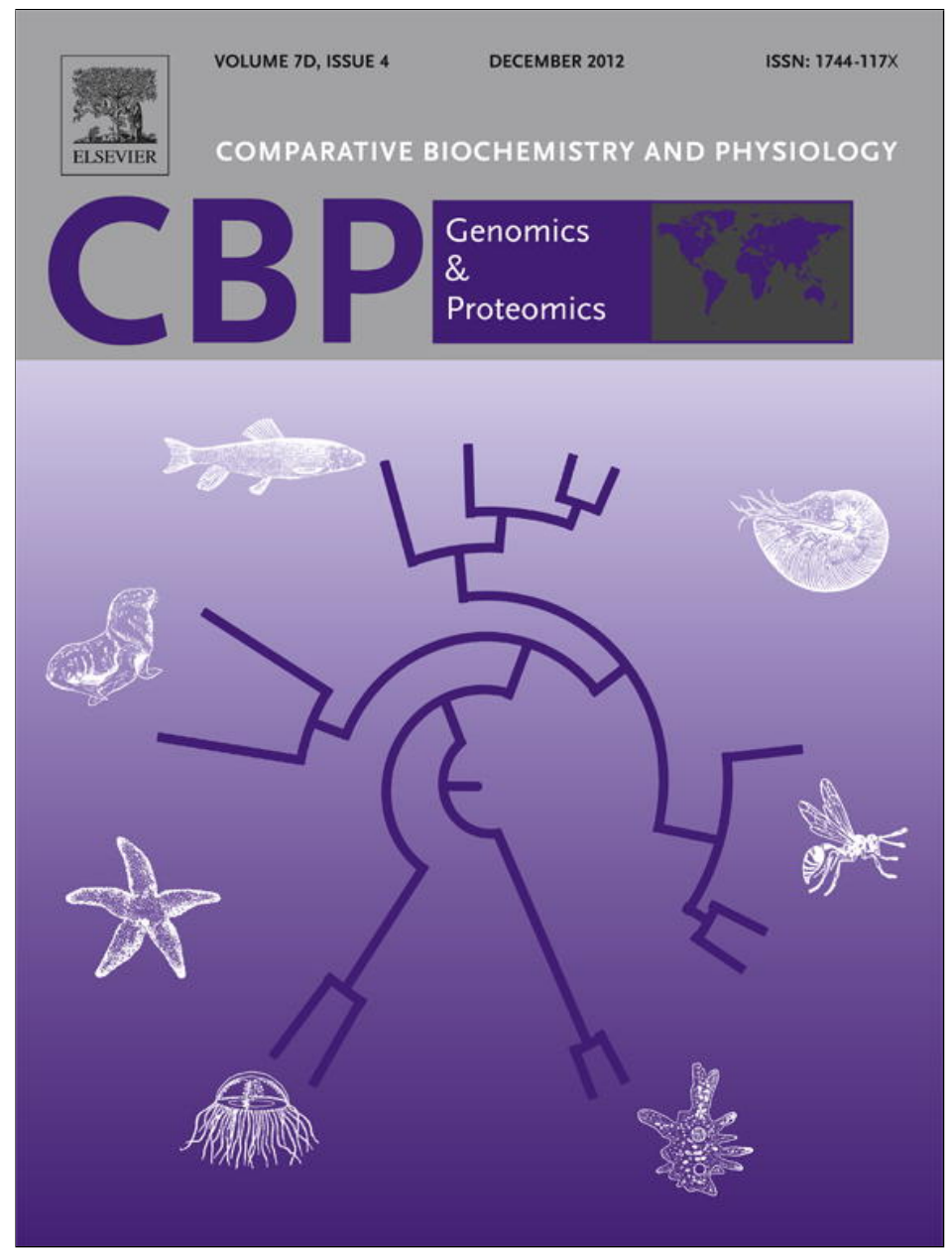

This article appeared in a journal published by Elsevier. The attached copy is furnished to the author for internal non-commercial research and education use, including for instruction at the authors institution and sharing with colleagues.

Other uses, including reproduction and distribution, or selling or licensing copies, or posting to personal, institutional or third party websites are prohibited.

In most cases authors are permitted to post their version of the article (e.g. in Word or Tex form) to their personal website or institutional repository. Authors requiring further information regarding Elsevier's archiving and manuscript policies are encouraged to visit:

http://www.elsevier.com/copyright 


\title{
Transcriptional profiling of the parr-smolt transformation in Atlantic salmon
}

\author{
Laura S. Robertson $^{\mathrm{a}, *}$, Stephen D. McCormick ${ }^{\mathrm{b}}$ \\ a USGS, Leetown Science Center, 11649 Leetown Road, Kearneysville WV 25430, USA \\ b USGS, Leetown Science Center, Conte Anadromous Fish Research Center, Turners Falls, MA 01376, USA
}

\section{A R T I C L E I N F O}

\section{Article history:}

Received 16 February 2012

Received in revised form 31 July 2012

Accepted 31 July 2012

Available online 7 August 2012

\section{Keywords:}

Expression

Microarray

Parr

Salmon

Smolt

Transcriptome

\begin{abstract}
A B S T R A C T
The parr-smolt transformation in Atlantic salmon (Salmo salar) is a complex developmental process that culminates in the ability to migrate to and live in seawater. We used GRASP 16K cDNA microarrays to identify genes that are differentially expressed in the liver, gill, hypothalamus, pituitary, and olfactory rosettes of smolts compared to parr. Smolts had higher levels of gill $\mathrm{Na}^{+} / \mathrm{K}^{+}$-ATPase activity, plasma cortisol and plasma thyroid hormones relative to parr. Across all five tissues, stringent microarray analyses identified 48 features that were differentially expressed in smolts compared to parr. Using a less stringent method we found 477 features that were differentially expressed at least 1.2-fold in smolts, including 172 features in the gill. Smolts had higher mRNA levels of genes involved in transcription, protein biosynthesis and folding, electron transport, oxygen transport, and sensory perception and lower mRNA levels for genes involved in proteolysis. Quantitative RT-PCR was used to confirm differential expression in select genes identified by microarray analyses and to quantify expression of other genes known to be involved in smolting. This study expands our understanding of the molecular processes that underlie smolting in Atlantic salmon and identifies genes for further investigation.
\end{abstract}

Published by Elsevier Inc.

\section{Introduction}

Atlantic salmon (Salmo salar) are anadromous fish that spend their early life history in freshwater, migrate to the ocean where they grow rapidly for one or two years, and then return to freshwater to spawn. The transformation of Atlantic salmon from stream-dwelling parr to seawater-tolerant smolts is a complex developmental process that involves changes in appearance (smolts are silvery and more streamlined than parr), behavior (parr are territorial, while smolts school), and physiology (McCormick et al., 1998). Physiological changes include alterations in the gill, gut and kidney that allow the fish to move from freshwater to seawater with minimal internal osmotic perturbations. Metabolism increases during smolting, and the liver develops an increased capacity for lipolysis and decreased capacity for lipid synthesis (Sheridan, 1989). Salmonids exhibit remarkable homing ability when they return to their natal streams to spawn and the parr-smolt transformation is a critical time for olfactory imprinting (Dittman et al., 1996) required for natal homing of returning adults (Dittman and Quinn, 1996). The molecular changes that drive this physiological development are still not well understood.

Several changes in gene expression during the parr-smolt transformation have been identified. Transcription of both gill $\mathrm{Na}^{+} / \mathrm{K}^{+}$-ATPase and gill vacuolar-type $\mathrm{H}^{+}$-ATPase changes significantly, but gradually, during the parr-smolt transformation (Seidelin et al., 2001). Several

\footnotetext{
* Corresponding author. Tel.: +1 304724 4579; fax: +1 3047244465.

E-mail address: lrobertson@usgs.gov (L.S. Robertson).
}

odorant receptor genes increase their rate of transcription during smolt development in Atlantic salmon (Dukes et al., 2004). Cytokine expression appears to be modulated during parr-smolt transformation (Ingerslev et al., 2006) and expression of transferrin is much higher in smolts than in parr (Hardiman and Gannon, 1996). Cytokines and transferrin are involved in immune responses. Expression and secretion of several hormones, including growth hormone, insulin-like growth factor I, cortisol, prolactin, and thyroid hormones are altered during smolting (McCormick et al., 1998). These hormones in turn may affect transcription of other genes involved in the parr-smolt transformation (Yada et al., 1992; Sakamoto et al., 1995), and are themselves controlled by hypothalamic factors. Brain and hypothalamic changes occur during smolt development, including increased numbers of corticotropin releasing factor neurons (Ebbesson et al., 2011), retinal innervation of the preoptic nucleus (Ebbesson et al., 2007) and altered opiate receptor distribution (Ebbesson et al., 1996). These changes may be critical to the altered photoperiod responsiveness that characterizes smolt development (Ebbesson et al., 2007; McCormick et al., 2007).

Microarrays provide a useful tool to look at transcriptional changes in a large number of genes. The GRASP 16K microarrays developed by the Genomic Research on Atlantic Salmon Project are spotted with 13,421 Atlantic salmon and 2576 rainbow trout cDNA features (von Schalburg et al., 2005b). These 16K chips and their 3K predecessors (Rise et al., 2004b) have been used to investigate the molecular differences between precociously mature male parr and immature males and females in Atlantic salmon (Aubin-Horth et al., 2005), ovary development in rainbow trout (von Schalburg et al., 
2005a, 2006), response to infectious hematopoietic necrosis virus (IHNV) vaccination in rainbow trout (Purcell et al., 2006), and the response of Atlantic salmon to Piscirickettsia salmonis infection (Rise et al., 2004a). As outlined above, there are important changes in osmoregulation, metabolism, and imprinting during smolt development that are cued by neuroendocrine mechanisms. In order to identify genes involved in smolt development, we used the GRASP $16 \mathrm{~K}$ microarray to compare gene expression between smolts and parr in tissues involved in osmoregulation (gill), metabolism (liver), imprinting (olfactory rosettes) and neuroendocrine control (hypothalamus and pituitary). Expression of select genes identified by microarray analyses was validated by qPCR. In addition, the expression of several genes known to be involved in smolting, but not represented on the GRASP arrays, was confirmed by qPCR.

\section{Materials and methods}

\subsection{Fish rearing and treatments}

Atlantic salmon of Connecticut River stock obtained as parr from the White River National Fish Hatchery in fall 2005 were reared at the Conte Anadromous Fish Research Center in Turners Falls, MA, USA. Fish were held in $1.5 \mathrm{~m}$ diameter fiberglass tanks receiving flow-through $\left(4 \mathrm{~L} \mathrm{~min}^{-1}\right)$ Connecticut River water $\left(\mathrm{Ca}^{2+}\right.$, $9.0 \mathrm{mg} \mathrm{L}^{-1} ; \mathrm{Mg}^{2+}, 1.5 \mathrm{mg} \mathrm{L}^{-1} ; \mathrm{Na}^{+}, 6.8 \mathrm{mg} \mathrm{L}^{-1} ; \mathrm{K}^{+}, 1.1 \mathrm{mg} \mathrm{L}^{-1}$; $\left.\mathrm{Cl}^{-}, 11.0 \mathrm{mg} \mathrm{L}^{-1}, \mathrm{pH} 6.8-7.8\right)$, maintained under natural photoperiod conditions. Fish were reared under ambient river temperatures through the fall and then at $10( \pm 1)^{\circ} \mathrm{C}$ from February through the remainder of the study. Fish were fed to satiation twice daily with commercial feed (Zeigler Bros., Garners, PA, USA). In late January, fish were divided into two groups and reared in separate tanks; fish smaller than $11 \mathrm{~cm}$ (parr) and greater than $12 \mathrm{~cm}$ (smolts). Previous studies have established these size thresholds for smolt development in Atlantic salmon (McCormick et al., 2007). Sixteen parr and sixteen smolts were sampled from each of two tanks ( 8 fish per tank, 4 tanks) on April 13, 2006 between 10:00 and 12:00 h Eastern Standard Time.

At the time of sampling, fish were euthanized in $200 \mathrm{mg} / \mathrm{L} \mathrm{MS}-222$ neutralized to $\mathrm{pH} 7.0$; fork length to the nearest millimeter and weight to the nearest $0.1 \mathrm{~g}$ were recorded. Blood was drawn from the caudal vein into $1 \mathrm{~mL}$ ammonium heparinized syringes and spun at $8000 \mathrm{~g}$ for $5 \mathrm{~min}$ at $4{ }^{\circ} \mathrm{C}$. Plasma was aliquoted and immediately stored at $-80^{\circ} \mathrm{C}$ for subsequent measurement of hormones. Four to six gill filaments were severed above the septum, placed in $100 \mu \mathrm{L}$ of ice-cold SEI buffer (150 mM sucrose, $10 \mathrm{mM}$ EDTA, $50 \mathrm{mM}$ imidazole, $\mathrm{pH} 7.3$ ) and immediately frozen at $-80{ }^{\circ} \mathrm{C}$. The remaining gill tissue was trimmed from gill arches for expression analysis. The hypothalamus was dissected as outlined in ((Okuzawa et al., 1990); see their Fig. 1). The hypothalamus was dissected with minimal tissue from the preoptic tectum and thalamus, and all dissections were carried out by the same individual to minimize variation. The gill, liver, pituitary, hypothalamus and both olfactory rosettes were collected in individual tubes, frozen immediately on dry ice and stored at $-80{ }^{\circ} \mathrm{C}$ for microarray analyses.

\subsection{Physiological assays}

Gill $\mathrm{Na}^{+}, \mathrm{K}^{+}$-ATPase activity was determined as described in McCormick (1993). Briefly, gill tissue was homogenized in $150 \mu \mathrm{L}$ of SEID (SEI buffer and 0.1\% deoxycholic acid) and centrifuged at $5000 \mathrm{~g}$ for $30 \mathrm{~s}$. Two sets of duplicate $10 \mu \mathrm{L}$ samples were run, one set containing assay mixture and the other assay mixture and $0.5 \mathrm{mM}$ ouabain. The resulting ouabain-sensitive ATPase activity (expressed as $\mu \mathrm{mol} \mathrm{ADP} / \mathrm{mg}$ protein/h) was quantified via a kinetic assay run in 96 -well microplates at $25^{\circ} \mathrm{C}$ and read at a wavelength of $340 \mathrm{~nm}$ for $10 \mathrm{~min}$. Protein concentrations were determined using BCA (bicinchoninic acid) Protein Assay (Pierce, Rockford, IL, USA). Both assays were run on a THERMOmax microplate reader using SOFTmax software (Molecular Devices, Menlo Park, CA, USA).
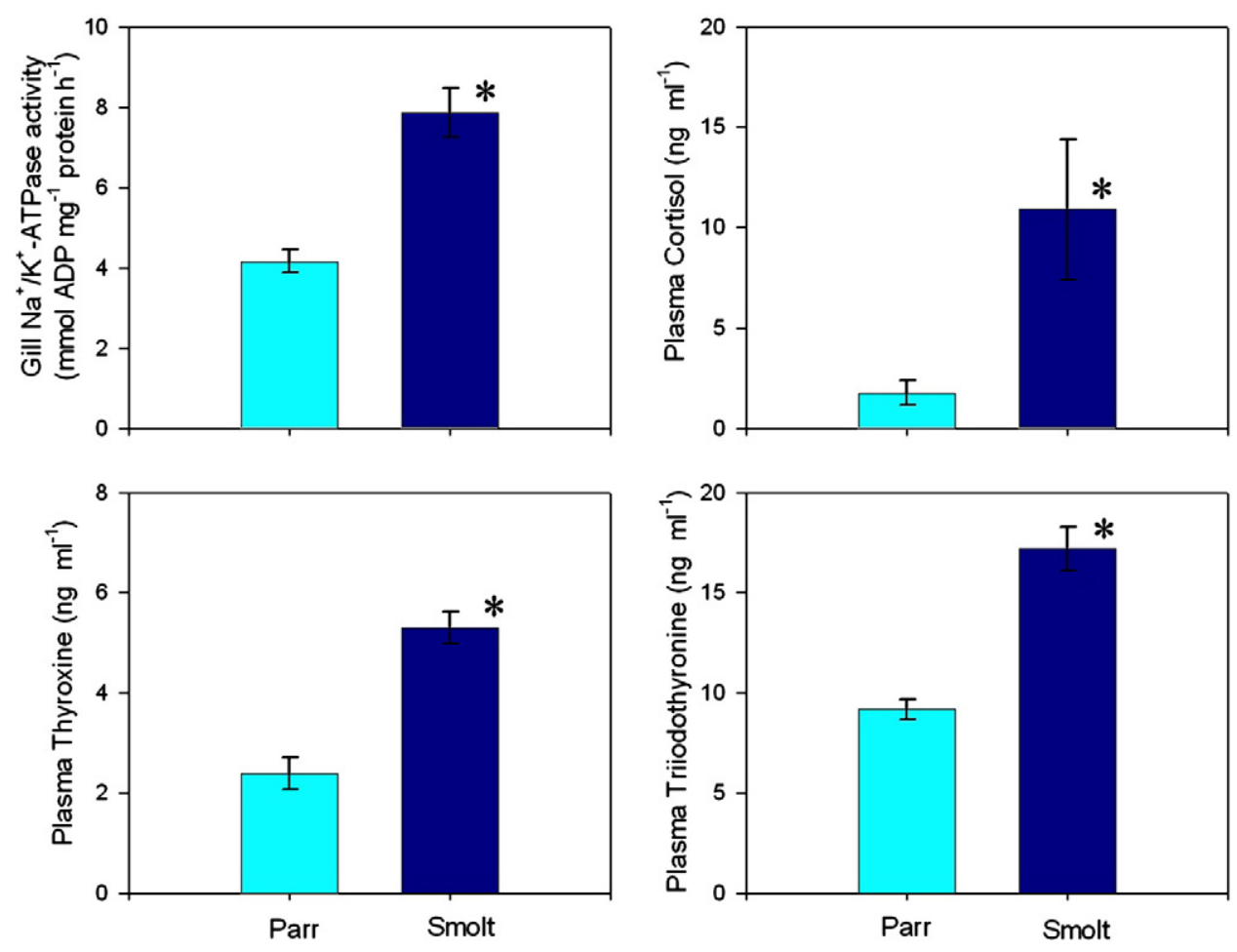

Fig. 1. Physiological and endocrine differences between Atlantic salmon parr and smolt sampled on April 13. Values are mean + standard error of $10-12$ fish per group. Asterisk indicates a significant difference between parr and smolt $(\mathrm{p}<0.05$, t-test). 
Plasma cortisol levels were measured by a validated direct competitive enzyme immunoassay as described by Munro and Stabenfeldt (Munro and Stabenfeldt, 1984) and modified by Carey and McCormick (Carey and McCormick, 1998). The assay range as defined by the standard curve was 1 to $200 \mathrm{ng} \mathrm{mL}^{-1}$. The lower detection limit was $0.3 \mathrm{ng} \mathrm{mL}{ }^{-1}$. Thyroxine $\left(\mathrm{T}_{4}\right)$ and 3,5,3'-triiodo-L-thyronine $\left(\mathrm{T}_{3}\right)$ concentrations were measured by a direct radioimmunoassay described by Dickhoff et al. (1978) and modified by McCormick et al. (1995). The range as defined by the standard curve was 1 to $64 \mathrm{ng} \mathrm{mL}^{-1}$ for $\mathrm{T}_{4}$ and $0.5-16 \mathrm{ng} \mathrm{mL}^{-1}$ for $\mathrm{T}_{3}$. Intra- and inter-assay coefficients of variation for these assays were $4-11 \%$ and $3-6 \%$, respectively.

\subsection{RNA isolation}

Total RNA was extracted from tissue samples frozen at $-80{ }^{\circ} \mathrm{C}$ using RNeasy kits (Qiagen, Inc., Valencia, CA, USA) according to manufacturer instructions; all samples were treated with RNase-free DNase (Qiagen) to remove genomic DNA contamination. RNA quantity was measured with an ND-1000 UV-vis Spectrophotometer (Nanodrop Technologies/ Thermo-Fisher Scientific, Inc., Wilmington, DE, USA). Quality of the RNA was assessed using a 2100 Bioanalyzer (Agilent Technologies, Inc., Santa Clara, CA, USA). The RNA Integrity Number (RIN) (Schroeder et al., 2006) for all samples used in the microarray hybridizations was greater than 8.0 ; 65 of the 76 samples had a RIN number of 9.0 or greater. RNA samples were stored at $-80^{\circ} \mathrm{C}$.

\subsection{Microarray hybridization}

GRASP 16K cDNA microarrays spotted with 16,006 features were purchased from the Genomics Research on All Salmon consortium (GRASP, http://web.uvic.ca/grasp/). These microarrays have been validated for salmonid species (von Schalburg et al., 2005b). Slide pre-processing, sample hybridization, and post-hybridization washing were performed as recommended by GRASP.

Pituitary and hypothalamus RNA were amplified, and then labeled using the Ambion Amino Allyl MessageAmpII aRNA amplification kit (Applied Biosystems/Life Technologies Corporation, Carlsbad, CA, USA) according to manufacturer's instructions. 100 ng or 200 ng RNA was reverse transcribed into complementary DNA (cDNA) using an oligo(dT) primer containing a T7 promoter, then copied to create double-stranded DNA. In a single round of amplification, this double-stranded DNA was used as a template to synthesize amino-allyl modified RNA (aRNA) with a T7 RNA polymerase in an $8 \mathrm{~h}$ in vitro transcription reaction. Amino-allyl modified, amplified RNA (5 $\mu$ g) was labeled with Alexa Fluor 555 or 647 dyes (Invitrogen/Life Technologies).

Liver, gill, and olfactory rosette RNA were not amplified prior to labeling. For these samples, cDNA containing amino-modified bases was synthesized using the Superscript Plus Indirect cDNA Labeling System (Invitrogen/Life Technologies) and labeled with Alexa Fluor 555 or 647 dyes (Invitrogen/Life Technologies) according to manufacturer's instructions, with the following minor modifications. Total RNA $(10 \mu \mathrm{g})$ was reverse transcribed into cDNA with a dNTP mixture that included the amino-modified nucleotides. Qiaquick PCR Purification spin columns (Qiagen) were used to clean the cDNA following first strand synthesis and following labeling with Alexa Fluor dyes.

Microarray slides from the same print batch were used for each tissue comparison. The print batch for the microarrays used in the smolt-parr gill, olfactory rosettes, hypothalamus, and pituitary comparisons had an unusable subarray (column 1, row 8) due to printing errors. Prior to hybridization, microarray slides were washed $10 \mathrm{~min}$ in $0.1 \% \mathrm{SDS}$, and then rinsed $5 \mathrm{~min}$ in ultrapure water. Slides were dried by centrifugation and pre-warmed at $50{ }^{\circ} \mathrm{C}$ for $30 \mathrm{~min}$. For each slide, 15 pmol of the Alexa 555 labeled aRNA or cDNA and 15 pmol of the Alexa 647 labeled aRNA or cDNA were combined and mixed with Ambion SlideHyb no. 2 (Applied Biosystems/Life
Technologies) to a volume of $60 \mu \mathrm{L}$ for hybridization. The combined samples and hybridization buffer were heated at $80^{\circ} \mathrm{C}$ for $10 \mathrm{~min}$ and pipetted under a LifterSlip coverslip (Erie Scientific/ThermoFisher Scientific, Inc., Wilmington, DE, USA) on top of the microarray slide. The slides were incubated at $50{ }^{\circ} \mathrm{C}$, shaking slowly, for $16-18 \mathrm{~h}$ in a Shake 'N' Bake hybridization oven (Boekel Scientific, Feasterville, PA, USA). After hybridization, slides were washed on an orbital shaker for 10 min in heated $2 \times$ SSC $+0.5 \%$ SDS; coverslips floated off the slides during this wash. Slides were then washed for $5 \mathrm{~min}$ in heated $2 \times$ SSC $+0.5 \%$ SDS, 5 min in $0.5 \times$ SSC, and 5 min in $0.05 \times$ SSC. Slides were dried by centrifugation and immediately scanned at $10 \mu \mathrm{m}$ resolution in a ScanArray Gx microarray scanner (Perkin Elmer, Waltham, MA, USA). Laser power and PMT voltage were adjusted using the Line Scan Protocol (ScanArray Microarray Analysis System version 3.0, Perkin Elmer) such that the signal from the Alexa Fluor 555 dye was approximately equal to the signal from the Alexa Fluor 647 dye for each slide and the signal was saturated for approximately $0.3-0.5 \%$ of the features on the slide.

\subsection{Array experimental design}

Thirty-eight microarray slides were used for a direct comparison of smolts and parr: eight two-channel slides each for liver, gill, olfactory rosettes, and hypothalamus tissues and six two-channel slides for pituitary. RNA was isolated from the tissues of eight parr (four males and four females) and eight smolts (four males and four females) and reverse transcribed separately (not pooled); each slide represented a biological replicate. For liver, gill, olfactory rosettes, and hypothalamus tissues, the arrays were balanced for sex and for dye: female parr were labeled with Alexa Fluor 555 and female smolts were labeled with Alexa Fluor 647 on two slides, female parr were labeled with Alexa Fluor 647 and female smolts were labeled with Alexa Fluor 555 on two slides, male parr were labeled with Alexa Fluor 555 and male smolts were labeled with Alexa Fluor 647 on two slides, and male parr were labeled with Alexa Fluor 647 and male smolts were labeled with Alexa Fluor 555 on two slides. For the pituitary comparison, only two arrays were used to compare female parr and female smolts, one with the female parr sample labeled with Alexa Fluor 555 and one with the female parr sample labeled with Alexa Fluor 647. Liver, gill, hypothalamus, pituitary, and olfactory rosette tissues were analyzed separately for each experiment, resulting in five distinct analyses.

\subsection{Microarray analysis}

Spot-finding was done with ScanArray Express Microarray Analysis System software version 4.0 using the adaptive circle method. Spot-finding images were manually reviewed and improperly identified spots were manually adjusted.

The TM4 Microarray Software Suite was used for pre-processing, filtering, normalization, and statistical analysis of the microarray data (Saeed et al., 2003). Files containing median spot intensities and median background intensities were imported into the TM4 Microarray Software using Express Converter version 2.1 utility; median background intensities were subtracted from median spot intensities. Converted intensity files were imported into TM4 Midas version 2.20 with RMA and spots where the background-corrected intensity was less than zero for either channel (dye) were removed. The $\log _{2}$ intensity ratios for each array were normalized using a local Lowess normalization (by subarray or block) and standard deviation regularization for the blocks. Lowess correction was done by block, or pin group, to correct for any differences between spotting pin or spatial differences across the slide. One-class Significance Analysis of Microarrays (SAM; TM4 MeV version 4.2) was used to identify genes with significantly different expression between conditions (smolts versus parr); the delta value was minimized such that the 
median false discovery rate (FDR) was less than 1.0 gene. One-class Significance Analysis of Microarrays was performed with all microarrays from a single tissue (six slides for pituitary; eight slides each for liver, gill, hypothalamus, and olfactory rosette tissues); differentially expressed genes were also identified by SAM within males and within females using the sex-specific slides. Fold-change values listed in Table 3 were calculated during t-test analysis. T-tests (TM4 MeV version 4.2; $\mathrm{p}<0.01$ or $\mathrm{p}<0.001$ ) were also used to identify genes with significantly different expression between conditions; results were filtered by fold-change using 1.2-fold and 2.0-fold thresholds. To investigate false discovery rate with t-test analyses, q-values were calculated using the QVALUE software written by Alan Dabney and John Storey (Storey and Tibshirani, 2003).

The translated sequences for features identified as differentially expressed in microarray analyses were compared to the SwissProt database using the blastp program (blast.ncbi.nlm.nih.gov; database accessed on December 6, 2010). The name of the blast hit having the lowest e-value is given as the "best BLAST hit" for each feature (Tables 1 and 3-6). Features that did not have a BLAST hit with e-value less than 1e-3 and features where the region of sequence similarity covered less than $50 \%$ of the translated feature sequence are indicated. Note that the best BLAST hit listed in these tables is not always the same as the annotation provided by the GRASP consortium.

\subsection{Real-time PCR analysis}

Real-time PCR was used to validate gene expression of select genes identified in microarray analyses. Gene expression was measured in 29 fish for the smolt-parr comparisons (16 smolts and 13 parr) in liver, including the 16 fish used for the microarray hybridizations, and 23 fish for the smolt-parr comparisons (15 smolts and 8 parr) in gill, including 13 of the 16 fish used for the microarray hybridizations. Real-time qRT-PCR was performed on an ABI7900HT (Applied Biosystems/Life Technologies) (Rajeevan et al., 2001). Alien QRT-PCR Inhibitor Alert kit (Agilent Technologies, Inc., Santa Clara, CA, USA) was used to verify the absence of QRT-PCR inhibitors in a representative subset of liver RNA samples from smolts and from parr. Total RNA ( $2 \mu \mathrm{g}$ ) was reverse transcribed in a $20 \mu \mathrm{L}$ reaction using the High Capacity cDNA Reverse Transcription Kit (Applied Biosystems/Life Technologies), according to manufacturer's instructions. Real-time PCR reactions ( $20 \mu \mathrm{L}$ total volume) contained $1 \mu \mathrm{L}$ cDNA (1:10 dilution of RT reaction), $7.5 \mu \mathrm{L}$ of $2 \times$ Power SYBR Green Master Mix (Applied Biosystems/Life Technologies), and $300 \mathrm{nM}$ each forward and reverse primers (see Table 1); cycling parameters were $50{ }^{\circ} \mathrm{C}$ for $2 \mathrm{~min}, 95{ }^{\circ} \mathrm{C}$ for $10 \mathrm{~min}$, then 40 cycles of $95{ }^{\circ} \mathrm{C}$ for $15 \mathrm{~s}$ followed by $60{ }^{\circ} \mathrm{C}$ for $1 \mathrm{~min}$. All cycling reactions were analyzed with a dissociation curve to verify amplification of a single product. All real-time PCR reactions (target genes and reference genes) were done in triplicate.

The relative standard curve method was used for quantification of gene expression. For the validation of genes identified in smolt-parr comparison, RNA from a female smolt, a male smolt, a female parr, and a male parr was pooled in a reverse transcription reaction. For each primer set, a serial dilution of the above mixed cDNA for the appropriate tissue was used to construct a standard curve for each assay plate. The standard curve was constructed by plotting the threshold cycle $(\mathrm{Ct})$ versus a copy number based on dilution factor. This curve was used to calculate relative abundance for the transcript of interest in each sample.

Mean expression of target gene divided by mean expression of a reference gene is reported. Statistical differences between parr and smolts were examined by Mann-Whitney U-test. EF1- $\alpha A$, EF1- $\alpha B$, 40S ribosomal protein S20, 40S ribosomal protein S13, and EST: ssallna005085 (GenBank accession no. CA038241) were considered as potential reference genes for qRT-PCR in the liver. mRNA abundance for each of these genes was measured in triplicate by qRT-PCR across 29 fish. Three values were considered for each gene: variation in $\mathrm{Ct}$ in number of cycles across the entire set, the average fold-change between smolt and parr, and the p-value from a MannWhitney test to assess statistical difference between parr and smolt. The EST: ssallna005085 was chosen as a reference gene for liver; for EST: ssallna005085, the variation in mean Ct across the set of 29 fish was 1.51 cycles, the fold-change between parr and smolt was 1.00 , and the p-value was 0.9825 . Similarly, $\beta$-actin and $40 \mathrm{~S}$ ribosomal protein S20 genes were considered as reference genes for the gill.

Table 1

Primer sequences used for real-time PCR.

\begin{tabular}{|c|c|c|c|}
\hline Gene or best BLAST hit ${ }^{\mathrm{a}}$ & Accession & Forward primer & Reverse primer \\
\hline$\beta$-actin & BG933897 & CCAAAGCCAACAGGGAGAAG ${ }^{\mathrm{b}}$ & AGGGACAACACTGCCTGGAT ${ }^{\mathrm{b}}$ \\
\hline CFTR-I & AF155237 & CCTTCTCCAATATGGTTGAAGAGGCAA $^{\mathrm{c}}$ & GAGGCACTTGGATGAGTCAGCAG ${ }^{\mathrm{C}}$ \\
\hline CFTR-II & AF161070 & GCCTTATTTCTTCTATTTGTATGCACTT ${ }^{\mathrm{c}}$ & GCCACCATGAAAAACTAAAGAGTACCTCAG \\
\hline${ }^{f}$ EST: ssallna005085 ${ }^{d}$ & CA038241 & GGCTGTGCTAGGCTGGAGTT & CGGTTCTGATGGCAGCACTT \\
\hline Hemoglobin subunit alpha-1 & CB498419 & CGATCTGCACGCCTTCAAC & TGTGGGACAGGATCTTGAAGTTT \\
\hline High choriolytic enzyme $2^{\mathrm{a}}$ & CA048927 & CCCGGGAGAGGTCCGTAA & CAGGTTGATGCAGCAAAGGTT \\
\hline${ }^{\mathrm{g}}$ Histone $\mathrm{H} 1^{\mathrm{a}}$ & CB491022 & GACСССТTСАСТСАССАТССТ & GGGACAATGCCGATTCTCA \\
\hline IGF-I & NM_001123623 & CAGTTCACGGCGGTCACATA & GCTCGCAACTCTGGAAGCA \\
\hline $\begin{array}{l}\text { Leukocyte cell-derived } \\
\text { chemotaxin- } 2^{\mathrm{a}}\end{array}$ & CX984314 & TGGGACCCTGCTGACCAT & ATCTGGACGTGGACGTGAGAA \\
\hline${ }_{\beta}^{\mathrm{g}}{ }_{\beta}-2-$ Microglobulin $^{\mathrm{a}}$ & CA042157 & GATCCCAGACGCCAAGCA & GTGGAACTGCCATCCCTGTT \\
\hline${ }^{\mathrm{g}}$ Nattectin ${ }^{\mathrm{a}}$ & CB511007 & TGACACCTGGGTTGGAGGTT & CCATCTGACCACATCCATAAGC \\
\hline NKA $\alpha-1 \mathrm{a}$ & CK878443 & CCAGGATCACTCAATGTCACTCT ${ }^{c}$ & $\begin{array}{l}\text { GCTATCAAAGGCAAATGAGTTTAATAT } \\
\text { CATTGTAAAA }^{c}\end{array}$ \\
\hline NKA $\alpha-1 b$ & CK879688 & GCTACATCTCAACCAACAACATTACAC ${ }^{c}$ & TGCAGCTGAGTGCACCAT $^{\mathrm{c}}$ \\
\hline NKA $\alpha-1 c$ & CK885259 & AGGGAGACGTACTACTAGAAAGCAT ${ }^{\mathrm{C}}$ & CAGAACTTAAAATTCCGAGCAGCAA $^{\mathrm{C}}$ \\
\hline $\begin{array}{l}{ }^{g} \text { Pancreatic progenitor } \\
\text { cell differentiation and } \\
\text { proliferation factor } \mathrm{B}^{\mathrm{a}}\end{array}$ & CB497819 & TGAAGAATGGCAGCGATCAA & CCTTCGGTAGTAGTCATTGGTAGCA \\
\hline 40S Ribosomal protein $\mathrm{S} 20^{\mathrm{e}}$ & BG936672 & GCAGACCTTATCCGTGGAGCTA $^{\text {b }}$ & TGGTGATGCGCAGAGTCTTG $^{\mathrm{b}}$ \\
\hline
\end{tabular}

a Best BLAST hit, see methods for BLAST parameters.

b Primers designed by Olsvik et al. (2005).

c Primers designed by Nilsen et al. (2007).

d Reference gene for liver tissue qPCR.

Reference gene for gill tissue $\mathrm{qPCR}$.

${ }^{f}$ No BLAST hit with E-value $<1 \mathrm{e}-3$.

$\mathrm{g}$ blastx query coverage less than $50 \%$. 
Expression of $\beta$-actin was almost three-fold higher in the gill of smolts compared to parr; 40S ribosomal protein S20 was chosen as a reference gene.

Primers for real-time PCR were designed using Primer Express version 3.0 (Applied Biosystems/Life Technologies); primer pairs were designed with a melting temperature of $58-60{ }^{\circ} \mathrm{C}$. Primers used in real-time PCR are listed in Table 1.

\section{Results}

\subsection{Physiological verification of developmental stage}

At the time of sampling in mid-April, parr were smaller than smolts (10-12 and 14-16 cm fork length, respectively). Parr had vertical dark bands on their sides, whereas smolts were silvery and had darkened fin margins. Gill $\mathrm{Na}^{+}, \mathrm{K}^{+}$-ATPase activity was approximately two-fold higher in smolts than in parr (Fig. 1, $\mathrm{p}<0.001$ ). Plasma cortisol was five-fold higher in smolts than in parr $(p=0.027)$. Plasma $\mathrm{T}_{4}$ and $\mathrm{T}_{3}$ were 2.5 -fold and 2.0-fold higher in smolts than in parr, respectively (Fig. $1, \mathrm{p}<0.001$ ).

\subsection{Genes differentially expressed in smolts compared to parr}

Gene expression was compared between Atlantic salmon smolts and parr in the gill, liver, olfactory rosettes, hypothalamus, and pituitary (five experiments) using GRASP 16K microarrays. The microarray data discussed here have been deposited in NCBI's Gene Expression Omnibus (Edgar et al., 2002) and are accessible through GEO Series accession number GSE33711 (http://www.ncbi.nlm.nih.gov/geo/query/acc.cgi? acc $=$ GSE33711). Table 2 lists the number of differentially expressed features identified by Significance Analysis of Microarrays (SAM) and by t-test at two significance levels $(\mathrm{p}<0.001$ and $\mathrm{p}<0.01$ ), for all five tissues. Features identified by SAM are listed in Table 3.

In the gill, thirteen features were significantly differentially expressed between smolts and parr (SAM); all thirteen features had higher abundance in parr than in smolts. Nineteen features were significantly more abundant in the livers of smolt compared to parr and one feature was significantly more abundant in the livers of parr compared to smolt (SAM). In the brain, five features were more abundant in the hypothalamus and two features were more abundant in the pituitary of smolts compared to parr. Eight features were identified by SAM in the olfactory rosettes; seven were more abundant in parr compared to smolts and one was more abundant in smolts compared to parr.

To facilitate comparison with other studies and to identify potentially interesting genes that may have been missed by SAM, the same microarrays were also analyzed by t-test $(\mathrm{p}<0.01)$, using a 1.2 -fold change threshold to filter results. Using this less stringent method, 172 features in the gill, 129 features in liver, 57 features in the hypothalamus, 31 features in the pituitary, and 88 features in the olfactory rosettes were significantly altered at least 1.2 -fold in smolts compared to parr. These features are described in Supplementary Tables

Table 2

Number of significantly differentially expressed features identified by t-test with $\mathrm{p}<0.001$ ( $\mathrm{t}$-test), by t-test with $\mathrm{p}<0.01$ and at least two-fold change in expression ( $\mathrm{t}$-test $\& 2 \times$ ), and by SAM analysis (SAM) in smolt compared to parr, by tissue.

\begin{tabular}{lcrcrr}
\hline & $\begin{array}{c}\mathrm{t} \text {-test, } \\
\mathrm{p}<0.001\end{array}$ & \multicolumn{3}{c}{$\mathrm{t}$-test, $\mathrm{p}<0.01$} & SAM \\
\cline { 3 - 5 } & & total & $\begin{array}{c}\geq 1.20 \text {-fold } \\
\text { change }\end{array}$ & $\begin{array}{c}\geq 2.00 \text { fold } \\
\text { change }\end{array}$ \\
\hline Liver & 26 & 196 & 129 & 12 & 20 \\
Gill & 27 & 358 & 172 & 2 & 13 \\
Hypothalamus & 10 & 95 & 57 & 0 & 5 \\
Pituitary & 11 & 62 & 31 & 0 & 2 \\
Rosettes & 21 & 239 & 88 & 1 & 8 \\
\hline
\end{tabular}

Table 3

Features significantly altered (SAM) in smolts compared to parr.

\begin{tabular}{|c|c|c|c|}
\hline Best BLAST hit & Accession & Tissue & $\begin{array}{l}\text { Fold } \\
\text { change }\end{array}$ \\
\hline $\begin{array}{l}{ }^{\mathrm{c}} \text { Cocaine- and amphetamine-regulated } \\
\text { transcript protein }\end{array}$ & СК991086 & Gill & 0.85 \\
\hline DNA replication licensing factor $\mathrm{mcm} 4$ & CA058937 & Gill & 0.88 \\
\hline bEST:omykrbna502145 & CB494649 & Gill & 0.82 \\
\hline 'EST:ssalga504353 & CB501767 & Gill & 0.87 \\
\hline bEST:ssalplnb506185 & CA043218 & Gill & 0.82 \\
\hline bEST:ssalrga514110 & CA051282 & Gill & 0.83 \\
\hline 'EST:ssalrgb549161 & CB517249 & Gill & 0.87 \\
\hline bEST:ssalrgb550321 & CB511946 & Gill & 0.82 \\
\hline 'EST:ssalrgb554085 & CB515466 & Gill & 0.88 \\
\hline${ }^{\mathrm{c}}$ Glyoxalase domain-containing protein 4 & CA053286 & Gill & 0.90 \\
\hline High choriolytic enzyme 2 & CA048927 & Gill & 0.38 \\
\hline Protein FAM199X & CB499701 & Gill & 0.51 \\
\hline T-complex protein 1 subunit delta & CB514946 & Gill & 0.85 \\
\hline bEST:omykrbhb007074 & CB498497 & Hypothalamus & 1.57 \\
\hline bEST:ssalmge502165 & CB506086 & Hypothalamus & 1.97 \\
\hline 'EST:ssalob003021 & CК990717 & Hypothalamus & 1.43 \\
\hline Hemoglobin subunit beta-1 & CB498416 & Hypothalamus & 1.70 \\
\hline Protein BTG3 & CB487722 & Hypothalamus & 1.71 \\
\hline${ }^{\mathrm{c}}$ Histone H1.0 & CB491022 & Liver & 0.34 \\
\hline 40 S ribosomal protein S20 & CB497418 & Liver & 1.72 \\
\hline${ }^{\mathrm{C} B r a i n}$ protein 44 -like protein & CB496707 & Liver & 1.60 \\
\hline${ }^{\mathrm{C}}$ Brain protein 44 -like protein & CK991275 & Liver & 1.30 \\
\hline bEST:omykrbna502240 & CB496899 & Liver & 1.36 \\
\hline 'EST:omykrbna502367 & CB497394 & Liver & 1.18 \\
\hline 'EST:omykrbnb003006 & CB496460 & Liver & 1.51 \\
\hline bEST:ssalrga511025 & CA063232 & Liver & 1.06 \\
\hline EST:ssalrgb502357 & CA062094 & Liver & 1.41 \\
\hline bEST:ssalrgb553185 & CB515254 & Liver & 1.33 \\
\hline bEST:ssalsrkc019061 & CB499820 & Liver & 1.30 \\
\hline $\begin{array}{l}{ }^{C} \text { Eukaryotic peptide chain release factor } \\
\text { GTP-binding subunit ERF3A }\end{array}$ & CB511708 & Liver & 1.17 \\
\hline${ }^{\mathrm{c} G a l a c t o k i n a s e}$ & CA063344 & Liver & 1.19 \\
\hline${ }^{\mathrm{c} H e a t}$ shock cognate $70 \mathrm{kDa}$ protein & CA767816 & Liver & 2.05 \\
\hline $\begin{array}{l}\text { Leukocyte cell-derived chemotaxin- } 2 \\
\quad \text { (LECT-2) }\end{array}$ & CX984314 & Liver & 1.58 \\
\hline $\begin{array}{l}\text { cLeukocyte cell-derived chemotaxin-2 } \\
\text { (LECT-2) }\end{array}$ & CA037891 ${ }^{\mathrm{a}}$ & Liver & 7.06 \\
\hline $\begin{array}{l}\text { 'Pancreatic progenitor cell differentiation } \\
\text { and proliferation factor B }\end{array}$ & СВ497819 & Liver & 1.47 \\
\hline Pre-mRNA-splicing factor CWC25 homolog & CB491162 & Liver & 1.11 \\
\hline SAGA-associated factor 29 homolog & CA055563 & Liver & 1.12 \\
\hline $\begin{array}{l}\text { Ubiquinone biosynthesis protein COQ9, } \\
\text { mitochondrial }\end{array}$ & CA043396 & Liver & 1.23 \\
\hline${ }^{\mathrm{C} C a l s e q u e s t r i n-1}$ & CB494076 & Pituitary & 1.46 \\
\hline bEST:ssalshc501091 & CA039833 & Pituitary & 1.48 \\
\hline $60 S$ ribosomal protein L19 & CB514402 & Rosettes & 0.88 \\
\hline 'Apolipoprotein A-I & CB510992 & Rosettes & 0.92 \\
\hline${ }^{\mathrm{C} E}$ longation factor 1-beta & CB517828 & Rosettes & 0.90 \\
\hline 'EST:ssalrga513211 & CA769782 & Rosettes & 0.89 \\
\hline 'EST:ssalrgb524305 & CA062983 & Rosettes & 0.92 \\
\hline bEST:ssalrgb535168 & CA063464 & Rosettes & 0.85 \\
\hline 'EST:ssalrgb549334 & CB517834 & Rosettes & 0.92 \\
\hline bEST:ssalrgb522072 & CA059235 & Rosettes & 1.24 \\
\hline
\end{tabular}

a Accession number for feature identified in microarray analysis; qPCR primers designed using CX984314, see Table 1.

b No BLAST hit with E-value $<1 \mathrm{e}-3$.

c blastx query coverage less than $50 \%$.

1-5. Q-values were calculated to investigate the false discovery rate in these t-test results. Based on these q-values, about $19 \%$ of features identified for gill, $76 \%$ of features identified for liver, $50 \%$ of features identified for olfactory rosettes, and all features identified for hypothalamus and pituitary may be false positives.

\subsection{Sex-specific differences in gene expression between smolts and parr}

Features identified as differentially expressed by SAM in male smolts compared to male parr are shown in Table 4 and features 
identified as differentially expressed by SAM in female smolts compared to female parr are shown in Table 5. Four features were identified in the gill: three features showed higher abundance in male parr compared to male smolts and one feature showed higher abundance in male smolts compared to male parr. Two features were identified in the hypothalamus and six features were identified in the pituitary; all eight features showed higher abundance in male smolts compared to male parr. No features were significantly differentially expressed between male smolts and male parr in the liver or olfactory rosettes. Thirty-eight features were significantly higher in the liver of female smolts compared to female parr (Table 5); no features were significantly higher in the liver of female parr compared to female smolts. No significant differences in expression between female smolts and female parr were identified in the gill, hypothalamus, or olfactory rosettes. Female-specific differences were not investigated in the pituitary because only two female parr and two female smolts were used in the microarray analysis in the pituitary.

\subsection{Genes differentially expressed in smolts compared to parr by $q R T-P C R$}

qRT-PCR was used to confirm the altered expression patterns identified by microarray analyses for three features (histone H1, leukocyte cell-derived chemotaxin 2 , and pancreatic progenitor cell differentiation and proliferation factor B) in the liver and one feature (high choriolytic enzyme) in the gill. The expression of all four of these features identified by microarray analysis was also significantly altered between smolt and parr by qRT-PCR (Table 6).

The expression of several genes that were identified by SAM as differentially expressed when considering only male fish or only female fish was also investigated by qRT-PCR. Nattectin (CB511007), a C-type fish lectin, was significantly decreased in smolt gills compared to parr using SAM to analyze the microarrays for male fish only. This dramatically reduced expression was confirmed for all smolts, both male and female, by qRT-PCR (Table 6). B2microglobulin (CA042157) was significantly upregulated in smolt liver compared to parr using SAM to analyze the microarrays for female fish only. Expression of $\beta 2$-microglobulin was 1.39 -fold higher in male smolts compared to male parr (Mann-Whitney $\mathrm{p}=0.2523), 1.41$-fold higher in female smolts compared to female parr (Mann-Whitney $\mathrm{p}=0.0503$ ), and 1.36-fold higher in smolts compared to parr (Mann-Whitney $\mathrm{p}=0.0460$ ) when males and females were grouped together. Pancreatic progenitor cell differentiation and proliferation factor B (CB497819) was identified as differentially expressed when all microarrays were considered (Table 3 ) and when only female fish were considered (Table 5). Expression of pancreatic progenitor cell differentiation and

\section{Table 4}

Features significantly altered (SAM) in male smolts compared to male parr; features more abundant in parr compared to smolts are listed above the divider line and features more abundant in smolts compared to parr are listed below the divider line.

\begin{tabular}{|c|c|c|}
\hline Best BLAST hit & Accession & Tissue \\
\hline High choriolytic enzyme 2 & CA048927 & Gill \\
\hline${ }^{\mathrm{b}}$ Nattectin & CB511007 & Gill \\
\hline aEST: ssalrgb509191 & CA062841 & Gill \\
\hline Hemoglobin subunit alpha-1 & CB498419 & Gill \\
\hline bJmjC domain-containing protein 8 & CB505201 & Hypothalamus \\
\hline $\begin{array}{l}\text { 'Phosphorylase b kinase gamma catalytic chain, } \\
\text { skeletal muscle isoform }\end{array}$ & CB486388 & Hypothalamus \\
\hline${ }^{\mathrm{b}}$ Calsequestrin-1 & СB494076 & Pituitary \\
\hline Myosin light chain 3 & СB492829 & Pituitary \\
\hline Paired amphipathic helix protein Sin3a & CA050074 & Pituitary \\
\hline${ }^{\mathrm{a} E S T:}$ ssalphc002066 & CA042911 & Pituitary \\
\hline${ }^{\mathrm{a} E S T}$ : ssalrgb544255 & CA058839 & Pituitary \\
\hline${ }^{\mathrm{a} E S T:}$ omykrtfh003092 & CB488737 & Pituitary \\
\hline
\end{tabular}

a No BLAST hit with E-value $<1 \mathrm{e}-3$.

b blastx query coverage less than $50 \%$.
Table 5

Features significantly altered (SAM) in female smolts compared to female parr; all features were more abundant in the livers of female smolts compared to female parr.

\begin{tabular}{|c|c|}
\hline Best BLAST hit & Accession \\
\hline $40 \mathrm{~S}$ ribosomal protein $\mathrm{S} 10$ & CB510496 \\
\hline $40 \mathrm{~S}$ ribosomal protein $\mathrm{S} 13$ & CB503487 \\
\hline 40S ribosomal protein S20 & CB497418 \\
\hline 60S ribosomal protein $\mathrm{L} 10 \mathrm{a}$ & CA060499 \\
\hline $60 S$ ribosomal protein $\mathrm{L} 10 \mathrm{a}$ & CA770456 \\
\hline b60S ribosomal protein L39 & CA046171 \\
\hline${ }^{\mathrm{b}}$ Barrier-to-autointegration factor & CB491851 \\
\hline${ }^{\mathrm{b} B e t a-2-m i c r o g l o b u l i n}$ & CA042157 \\
\hline Claudin-10 & CB494121 \\
\hline DNA-directed RNA polymerases I, II, and III subunit RPABC1 & CB496608 \\
\hline aEST: omykrbna003038 & CB492648 \\
\hline aEST: omykrbna502240 & CB496899 \\
\hline${ }^{\mathrm{a} E S T:}$ omykrbna505034 & CK991342 \\
\hline${ }^{\mathrm{a} E S T}$ : ssallna016029 & CA769178 \\
\hline aEST: ssalmge501296 & CB502545 \\
\hline aEST: ssalnwh502231 & CB511310 \\
\hline aEST: ssalnwh503341 & CB509635 \\
\hline aEST: ssalnwh506131 & CB510503 \\
\hline aEST: ssalnwh506268 & CB510672 \\
\hline aES: ssalplnb512149 & CA041792 \\
\hline${ }^{a}$ EST: ssalrgb523347 & СК991089 \\
\hline aEST:omykrbna505146 & CB492559 \\
\hline${ }^{\mathrm{b}}$ Eukaryotic translation initiation factor 1 & CB489126 \\
\hline Ferritin, heavy subunit & CB493178 \\
\hline Ferritin, heavy subunit & CB496534 \\
\hline${ }^{\mathrm{b}}$ Gamma-secretase subunit PEN-2 & CB510671 \\
\hline Glutathione S-transferase theta-1 & CB510883 \\
\hline Hemagglutinin/amebocyte aggregation factor & CB509470 \\
\hline Hemoglobin subunit alpha-1 & CB498419 \\
\hline Hemoglobin subunit beta-1 & CA049299 \\
\hline${ }^{\mathrm{b}} \mathrm{NADH}$ dehydrogenase [ubiquinone] 1 alpha subcomplex subunit 4 & CA038166 \\
\hline Nucleoside diphosphate kinase B & CB510537 \\
\hline bancreatic progenitor cell differentiation and proliferation factor B & CB497819 \\
\hline Secreted phosphoprotein 24 & CB492943 \\
\hline Secreted phosphoprotein 24 & CB510628 \\
\hline Transcription factor BTF3 homolog 4 & CB492449 \\
\hline Tumor protein D52 & CA038353 \\
\hline Ubiquitin-60S ribosomal protein $\mathrm{L} 40$ & CA767659 \\
\hline
\end{tabular}

proliferation factor B was 1.59-fold higher in male smolts compared to male parr (Mann-Whitney $\mathrm{p}=0.0549$ ), 1.79 -fold higher in female smolts compared to female parr (Mann-Whitney $\mathrm{p}=$

Table 6

Expression of selected genes as measured by qPCR; fold change is the mean normalized abundance in smolt divided by the mean normalized mRNA abundance in parr.

\begin{tabular}{|c|c|c|c|c|}
\hline Gene (or best BLAST hit ${ }^{\mathrm{a}}$ ) & Accession & Tissue & Fold change & p-value \\
\hline$\beta$-actin & BG933897 & Gill & 2.93 & 0.0106 \\
\hline CFTR-I & AF155237 & Gill & 2.22 & 0.0022 \\
\hline CFTR-II & AF161070 & Gill & 0.61 & 0.0041 \\
\hline Hemoglobin subunit, alpha-1 & CB498419 & Gill & 1.94 & 0.0359 \\
\hline High choriolytic enzyme $1^{\mathrm{a}}$ & CA048927 & Gill & 0.25 & 0.0002 \\
\hline Nattectin $^{\mathrm{a}}$ & CB511007 & Gill & 0.03 & 0.0009 \\
\hline NKA $\alpha-1 \mathrm{a}$ & CK878443 & Gill & 0.58 & 0.042 \\
\hline NKA $\alpha-1 b$ & CK879688 & Gill & 1.49 & 0.1138 \\
\hline NKA $\alpha-1 \mathrm{c}$ & CK885259 & Gill & 0.64 & 0.0074 \\
\hline 40S Ribosomal protein $\mathrm{S} 20^{\mathrm{b}}$ & BG936672 & Gill & 0.91 & 0.1293 \\
\hline EST: ssallna005085 & CA038241 & Liver & 1.00 & 0.9825 \\
\hline Histone $\mathrm{H}^{\mathrm{a}}$ & СВ491022 & Liver & 0.21 & $<0.0001$ \\
\hline IGF-I & NM_001123623 & Liver & 1.78 & 0.0004 \\
\hline $\begin{array}{l}\text { Leukocyte cell-derived } \\
\text { chemotaxin- } 2^{\mathrm{a}}\end{array}$ & CX984314 & Liver & 7.76 & $<0.0001$ \\
\hline$\beta$-2-Microglobulin ${ }^{\mathrm{a}}$ & CA042157 & Liver & 1.36 & 0.0460 \\
\hline $\begin{array}{l}\text { Pancreatic progenitor cell } \\
\text { differentiation and } \\
\text { proliferation factor } \mathrm{B}^{\mathrm{a}}\end{array}$ & CB497819 & Liver & 1.62 & 0.0041 \\
\hline
\end{tabular}


0.0503), and 1.62-fold higher in smolts compared to parr (MannWhitney $\mathrm{p}=0.0041$ ) when females and males were grouped together. The expression of hemoglobin alpha-1 (CB498419), which was significantly increased in the liver of female smolts compared to female parr and in the gill of male smolts compared to male parr by microarray analysis, was upregulated in smolt gills, by qRT-PCR (Table 6).

Insulin-like growth factor 1 (IGF-1) was not identified as differentially expressed in smolts compared to parr by microarray analysis. However, IGF-I transcription was increased in the livers of smolts compared to parr by qRT-PCR; the change was less than two-fold, but significant (Table 6).

Expression of several genes involved in ion regulation in the gill, but not represented on the GRASP $16 \mathrm{~K}$ array, was investigated by qRT-PCR. The salmon gill $\mathrm{Na}^{+}, \mathrm{K}^{+}$-ATPase (NKA) enzyme consists of two subunits ( $\alpha$ and $\beta$ ), with multiple isoforms for each subunit. Expression of NKA- $\alpha 1 \mathrm{a}$ and NKA- $\alpha 1 \mathrm{c}$ was decreased in smolts compared to parr; expression of NKA- $\alpha 1 \mathrm{~b}$ was increased in smolts compared to parr by 1.5 -fold, but the difference in expression was not significant (Table 6). There are two isoforms of the cystic fibrosis transmembrane conductance regulator (CFTR-I and CFTR-II). Expression of CFTR-I was increased more than two-fold in smolts compared to parr, while the expression of CFTR-II was decreased in smolts compared to parr (Table 6 ).

$\beta$-actin and 40S ribosomal protein S20 genes were investigated as possible reference genes for qRT-PCR in the gill. Expression of $\beta$-actin was almost three-fold higher in the gill of smolts compared to parr (Table 6), making it unsuitable as a reference gene for this experiment. The 40S ribosomal protein S20 was used for normalization of the gill qRT-PCR assays. In the liver, 40S ribosomal protein S20 was significantly higher in smolt than in parr by microarray analysis (CB497418; see Table 3). EF1- $\alpha \mathrm{A}, \mathrm{EF} 1-\alpha \mathrm{B}, 40 \mathrm{~S}$ ribosomal protein S20, 40S ribosomal protein S13, and EST: ssallna005085 (CA038241) were considered as potential reference genes for qRT-PCR in the liver; the EST: ssallna005085 was used for normalization of the liver qRT-PCR assays.

\section{Discussion}

\subsection{Microarray analyses}

We used the GRASP 16K microarray to investigate transcriptional changes during smolt development in five different tissues (gill, liver, olfactory rosettes, pituitary, and hypothalamus). Parr and smolts were identified by size and by physical appearance and confirmed by physiological measurement of gill $\mathrm{Na}^{+} / \mathrm{K}^{+}$-ATPase activity, plasma cortisol, and plasma $\mathrm{T}_{4}$ and $\mathrm{T}_{3}$. Differential gene expression was validated by qRT-PCR for select genes. By comparing parr and smolt at the same time, ours is the first study to identify molecular changes in multiple tissues that are specifically related to the parr-smolt transformation. Relative to parr, smolts had higher mRNA abundances for genes involved in the regulation of transcription, protein biosynthesis and folding, electron transport, oxygen transport, and sensory perception and lower mRNA levels for genes involved in proteolysis.

Microarray analysis is an extremely useful screening tool that facilitates the identification of genes that are differentially expressed between experimental conditions or developmental states; however, it is difficult to balance the identification of all biologically significant expression changes with the removal of all the non-significant changes. We identified genes with potentially significant differences in expression both by Significance Analysis of Microarrays (SAM), with a false discovery rate correction, and by t-test, filtered by fold change in RNA abundance. The use of t-tests identifies a much larger set of genes that may be biologically relevant, but that are missed by more stringent SAM analysis. Care needs to be taken with these less stringent results as they are likely to include false positives. However, the use of t-tests for analysis in this study also facilitates comparison with other microarray studies (e.g. Seear et al., 2010) that used t-tests for analysis. The commonly used two-fold change threshold, while convenient, may be too stringent for many biological processes, such as developmental events that occur over weeks. For example, Guiry et al. found no significant changes that were two-fold or higher in a comparison of gene expression in the brain between precocious Atlantic salmon males and non-precocious male parr, the greatest change in expression was 1.9-fold (Guiry et al., 2010). Our study surveyed gene expression in multiple tissues at a single time point during the middle of smolt development. Many of the gene expression differences that have been identified previously are moderate (less than two-fold) and occur over the entire several month period of smolt development. Thus, the moderate fold-changes observed in the present study may be characteristic of relatively slow developmental events like the parr-smolt transformation.

Seear et al. used the Atlantic salmon Transcriptome Analysis of Important Traits Salmon/Salmon Genome Project (TRAITS/SGP) cDNA microarray to identify genes differentially expressed during smolting in brain, gill, and kidney tissues (Seear et al., 2010). They identified 148 features that were differentially expressed ( $t$ test, $\mathrm{p}<0.01$ ) at least two-fold in the gills of parr (or pre-smolts) in winter compared to smolts in spring. These results need to be interpreted with some caution as they are not corrected for false discoveries. We identified only two features that were differentially expressed at least two-fold (t-test, $\mathrm{p}<0.01$ ) in smolt gills compared to parr; however, 172 features were differentially expressed at least 1.20fold. Additionally, Seear et al. identified 69 features differentially expressed at least two-fold in the brain of smolts compared to parr (Seear et al., 2010). We found no features differentially expressed at least two-fold in the pituitary or hypothalamus; however, 57 features in the hypothalamus and 31 features in the pituitary were differentially expressed at least 1.2-fold. Not all of the features on the TRAITS array or the GRASP array are unique genes; a gene can be represented by multiple features (sequences). For example, of the 138 features identified by Seear et al. to be upregulated at least two-fold in gill, ten features are $\alpha$ - and $\beta$-globin genes (Seear et al., 2010). Similarly, of the 61 features identified in this study to be increased in the gill, six are $\alpha$ - and $\beta$-globin genes. While several genes, listed below, were identified in both studies, most genes were identified in only one of these two studies. In both studies, expression of $\alpha$ - and $\beta$-globin genes was upregulated in the gill and in the brain or hypothalamus of smolts compared to parr and expression of cytochrome b was upregulated in smolt gill. Expression of collagen alpha-2(I) chain (CB509170) was upregulated 1.4-fold in the hypothalamus of smolts compared to parr ( $\mathrm{t}$-test, $\mathrm{p}<0.01$; this study) and upregulated 2.4-fold in the brain (CK884207) and 3.0-fold in the gill (CK884207) of smolt compared to parr in Seear et al. (Seear et al., 2010). Expression of NKA- $\alpha 1$ (CB517130) was upregulated 1.3-fold in gill of smolts compared to parr ( $\mathrm{t}$-test, $\mathrm{p}<0.01$; this study) and identified as upregulated 2.1-fold (CK886667) by Seear et al. (Seear et al., 2010). The small overlap between these studies may be due to several factors. Some of the differences between the two studies can be explained by the different microarrays used (TRAITS versus GRASP), with each array containing a different set of sequence probes. In addition, annotation for most features on each array is predicted by sequence similarity of the short sequence fragment used on the array to other publically available sequences; many features encode hypothetical proteins and many genes have not been biologically characterized. Also, Seear et al. (2010) compared parr (pre-smolts) collected in February with smolts collected in April, and thus incorporated an uncontrolled factor of seasonal influence, e.g. any change that occurs from winter to spring or is influenced by increased temperature during this period. In the present study, parr and smolts (the latter having reached the minimum size for smolt development (McCormick et al., 1998)) were collected on the same date. This 
approach avoided the seasonal factor and thus likely identified smolt-specific changes.

\subsection{Osmoregulation}

Increased salinity tolerance is a critical adaptive feature of smolt development, and there are many changes in gene expression in the gill that are linked to the increased salt secretory capacity of the gill. Gill $\mathrm{Na}^{+} / \mathrm{K}^{+}$-ATPase is involved in the osmoregulatory ability of Atlantic salmon and expression of different alpha subunit isoforms changes during smolting: mRNA abundance of the NKA- $\alpha 1$ a isoform decreases and NKA- $\alpha 1 b$ increases transiently during smolting, while expression of NKA- $\alpha 1$ c does not change significantly (Nilsen et al., 2007). One feature representing NKA- $\alpha 1 \mathrm{~b}$ and three features representing NKA- $\alpha 1 \mathrm{c}$ are on the GRASP array; NKA- $\alpha 1$ a is not on the GRASP array. The only NKA- $\alpha 1$ isoform identified as potentially differentially expressed in the gill by microarray was NKA- $\alpha 1 \mathrm{c}$ (CB517130); NKA- $\alpha 1 \mathrm{c}$ was 1.3 -fold higher in smolts than parr and significant by t-test $(\mathrm{p}<0.01)$, but not significant by SAM. Expression of NKA- $\alpha 1 \mathrm{c}$ was lower in smolts than parr by qRT-PCR. This was the only gene in this study where the change in expression seen in qRT-PCR was in the opposite direction of the change seen by microarray.

The transition from freshwater adapted parr to seawater tolerant smolt takes place over several months (generally from February to May or June). In a time course from February to June, Seidelin et al. observed an increase in total NKA- $\alpha$ mRNA abundance to a peak of approximately 2.3-fold higher in April compared to February, then a decrease in June to February levels (Seidelin et al., 2001). Over the same period, NKA activity increased to a peak in May of eight-fold higher than in February, then decreased in June; peak salinity tolerance was observed in May (Seidelin et al., 2001). The pattern observed by Nilsen et al. was similar, but shifted slightly later (Nilsen et al., 2007). NKA $\alpha$ mRNA abundance peaked in the middle of May at six-fold higher than February, then decreased in June; NKA activity steadily increased to a maximum of six-fold higher in June compared to February (Nilsen et al., 2007). We sampled both parr and smolt at a single time point in April. This removes the confounding factor of season, but does not allow the progression of NKA expression and activity to be followed across smolt development. At this time point, NKA activity was approximately two-fold higher in smolt than in parr $(\mathrm{p}<0.001)$ and $\mathrm{NKA} \alpha-1 \mathrm{~b}$ mRNA abundance was approximately 1.5 -fold higher in smolt than in parr ( $\mathrm{qPCR}, \mathrm{p}=0.1138$, not significant). These changes in NKA mRNA abundance and activity are consistent with those observed by Seidelin et al. and Nilsen et al. early in the smolting process.

CFTR is an apical $\mathrm{Cl}$ channel that is critical for salt secretion by the gills of teleost fish (Marshall et al., 1995). Gill CFTRI (but not CFTRII) mRNA abundance increases during smolt development (Nilsen et al., 2007), and mRNA abundance of gill CFTR I increases throughout seawater acclimation, whereas gill CFTR II increases transiently in smolts following transfer to seawater (Singer et al., 2002). The CFTR I and CFTR II genes are not represented on the GRASP array; however, by qRT-PCR, CFTR-I abundance was higher and CFTR-II abundance was lower in the gills of smolts compared to parr. Another gene with suggested involvement in osmoregulation, the sodium/glucose cotransporter 1 (SGLT1), was decreased 1.4-fold in the gills of smolts compared to parr. Expression of the sodium/glucose cotransporter is increased in the gills of green crabs following transfer to less saline water (Towle et al., 2011). Expression of cold-inducible RNA-binding protein was increased in the liver of smolts compared to parr. Expression of this gene has previously been shown to be upregulated by hyperosmotic stress in the gill of Atlantic salmon (Pan et al., 2004).

\subsection{Electron transport and oxygen transport}

Messenger RNA levels of $\alpha$ - and $\beta$-globin genes were higher in the gill, hypothalamus, and liver of smolts compared to parr (this study).
Elevated hemoglobin protein is seen in the blood of smolts (Sullivan et al., 1985). Expression of several features possibly involved in electron transport, including cytochrome $\mathrm{c}$ oxidase in the gill and hypothalamus and cytochrome $b$ in the gill, were increased in smolts compared to parr. Increased expression of these genes may be involved in meeting increased energy demands during smolt development and migration. Hepatic cytochrome c oxidase enzyme activity is higher in smolts than parr (Blake et al., 1984).

\subsection{Endocrinology}

In the pituitary, several changes in the expression of hormone genes have been noted: prolactin and growth hormone expression increase late during smolt transformation (Agustsson et al., 2003) and somatolactin mRNA decreases during smolting (O'Keeffe et al., 2008). While we found that somatolactin (GenBank accession no. CA046975) mRNA abundance was decreased slightly in the pituitary and expression of melanin-concentrating hormone (CA061912) was slightly higher in both the gill (1.3-fold) and the hypothalamus (1.2-fold) of smolts compared to parr, none of these changes were significant by SAM. We found increased levels of plasma $T_{4}$ and $T_{3}$ in smolts; however, we did not find higher levels of pituitary thyroid-stimulating hormone (TSH) mRNA by microarray. Although TSH is the primary stimulant of T4 production and release by the thyroid, recent studies in coho salmon (Oncorhynchus kistuch) found that pituitary TSH mRNA levels decrease during smolting, plasma and pituitary TSH do not change, yet plasma thyroid hormones increase (Larsen et al., 2011). Increased circulating thyroid hormones in the absence of large changes in TSH can be explained by an observed increase in thyroid sensitivity to TSH that occurs during smolt development (Specker and Schreck, 1984).

Five features were significantly increased in the hypothalamus of smolts compared to parr (SAM), including predicted hemoglobin beta, predicted protein BTG3, and three features with no significant similarity to known proteins. Increased mRNA levels of $\alpha$ - and $\beta$-globin genes are seen in the brain of early migrants compared to late migrants (Aubin-Horth et al., 2009) and in the brain and gill of pre-smolts compared to smolts (Seear et al., 2010). In mammals, BTG3 is a growth suppressor that may also be involved in neurogenesis (Ou et al., 2007; Siebzehnrubl et al., 2007). In rainbow trout, btg3 is predominantly expressed in oocytes and may be involved in oocyte development (Bobe et al., 2008). Two features were significantly increased in the pituitary of smolts compared to parr: predicted calsequestrin- 1 and one feature with no significant similarity to known proteins. Calsequestrin is a calcium-binding protein that may be involved in hypothermia and heat stroke; mice lacking calsequestrin are more likely to die in response to heat stress and the effect in more pronounced in males than females (Protasi et al., 2009). Calsequestrins are expressed in thermogenic cells of several fish (Block et al., 1994). Four calsequestrins have been identified in Senegalese sole; the calsequestrin- 1 isoforms are most highly expressed in skeletal muscle and the calsequestrin-2 isoforms are most highly expressed in the heart and brain (Infante et al., 2011).

\subsection{Protein biosynthesis, hsc70, and proteolysis \& peptidolysis}

Multiple ribosomal proteins involved in protein synthesis increased in smolt liver compared to parr. Increased capacity for both protein synthesis and proteolysis would be a logical requirement of the metamorphic-like changes and the overall increase in metabolic rate that occurs during smolt development (McCormick and Saunders, 1987). In addition, expression of the heat shock cognate $71 \mathrm{kDa}$ protein (Hsc70; GenBank accession no. CA767816) was increased 2.1-fold in the liver of smolts compared to parr. Fowler et al. found higher expression of Hsc70 in the livers of adult rainbow trout compared to fingerlings (Fowler et al., 2009). The expression of Hsc70, the heat shock 
protein Hsp70, and the heat shock transcription factor Hsf1 all increase with increasing salinity in the gill of sea bream; however only Hsc70, and not Hsp70 nor Hsf1, expression increases with salinity in liver of sea bream (Deane and Woo, 2004).

The parr-to-smolt transition is a critical and also very sensitive point in the development of Atlantic salmon. Several studies have begun to investigate the transcriptional changes underlying this complex developmental process (Aubin-Horth et al., 2009; Seear et al., 2010). This study is the first to identify transcriptional changes in multiple tissues that are specific to the parr-smolt transformation. We used the GRASP 16K cDNA array to identify transcriptional changes in gill, liver, hypothalamus, pituitary, and olfactory rosettes. To isolate developmental changes independently of season, parr and smolt tissue samples were collected on the same day early in smolt development. As discussed above, some of these genes have been identified previously; however, many new genes were found to be involved in the parr-smolt transformation. Several of these genes are candidates for further study to determine their relationship to increased performance (such as survival and growth in seawater), as critical factors triggering smolting, and as markers for smolt development. In addition, sex-specific transcriptional changes were identified. This study complements previous studies and expands our understanding of the transcriptional alterations across multiple tissues involved in a critical developmental process.

\section{Acknowledgments}

The authors thank Jamie Marie Marranca, Amy Regish and Michael O'Dea for technical assistance. This work was funded by the U.S. Geological Survey. Any use of trade, product, or firm names is for descriptive purposes only and does not imply endorsement by the U.S. Government.

\section{Appendix A. Supplementary data}

Supplementary data to this article can be found online at http:// dx.doi.org/10.1016/j.cbd.2012.07.003.

\section{References}

Agustsson, T., Sundell, K., Sakamoto, T., Ando, M., Bjornsson, B.T., 2003. Pituitary gene expression of somatolactin, prolactin, and growth hormone during Atlantic salmon parr-smolt transformation. Aquaculture 222, 229-238.

Aubin-Horth, N., Landry, C.R., Letcher, B.H., Hofmann, H.A., 2005. Alternative life histories shape brain gene expression profiles in males of the same population. Proc. R. Soc. Biol. Sci. B 272, 1655-1662.

Aubin-Horth, N., Letcher, B.H., Hofmann, H.A., 2009. Gene-expression signatures of Atlantic salmon's plastic life cycle. Gen. Comp. Endocrinol. 163, 278-284.

Blake, R.L., Roberts, F.L., Saunders, R.L., 1984. Parr-smolt transformation of Atlantic salmon (Salmo salar): activities of two respiratory enzymes and concentrations of mitochondria in the liver. Can. J. Fish. Aquat. Sci. 41, 199-203.

Block, B.A., Obrien, J., Meissner, G., 1994. Characterization of the sarcoplasmic-reticulum proteins in the thermogenic muscles of fish. J. Cell Biol. 127, 1275-1287.

Bobe, J., Nguyen, T., Mahe, S., Monget, P., 2008. In silico identification and molecular characterization of genes predominantly expressed in the fish oocyte. BMC Genomics 9 (Article No.: 499).

Carey, J.B., McCormick, S.D., 1998. Atlantic salmon smolts are more responsive to an acute handling and confinement stress than parr. Aquaculture 168, 237-253.

Deane, E.E., Woo, N.Y.S., 2004. Differential gene expression associated with euryhalinity in sea bream (Sparus sarba). Am. J. Physiol. 287, R1054-R1063.

Dickhoff, W.W., Folmar, L.C., Gorbman, A., 1978. Changes in plasma thyroxine during smoltification of coho salmon, Oncorhynchus kisutch. Gen. Comp. Endocrinol. 36, 229-232.

Dittman, A.H., Quinn, T.P., 1996. Homing in Pacific salmon: mechanisms and ecological basis. J. Exp. Biol. 199, 83-91

Dittman, A.H., Quinn, T.P., Nevitt, G.A., 1996. Timing of imprinting to natural and artificial odors by coho salmon (Oncorhynchus kisutch). Can. J. Fish. Aquat. Sci. 53, 434-442.

Dukes, J.P., Deaville, R., Bruford, M.W., Youngson, A.F., Jordan, W.C., 2004. Odorant receptor gene expression changes during the parr-smolt transformation in Atlantic salmon. Mol. Ecol. 13, 2851-2857.

Ebbesson, L.O.E., Deviche, P., Ebbesson, S.O.E., 1996. Distribution and changes in mu- and kappa-opiate receptors during the midlife neurodevelopmental period of coho salmon, Oncorhynchus kisutch. J. Comp. Neurol. 366, 448-464.
Ebbesson, L.O.E., Ebbesson, S.O.E., Nilsen, T.O., Stefansson, S.O., Holmqvist, B., 2007. Exposure to continuous light disrupts retinal innervation of the preoptic nucleus during parr-smolt transformation in Atlantic salmon. Aquaculture 273, 345-349.

Ebbesson, L.O.E., Nilsen, T.O., Helvik, J.V., Tronci, V., Stefansson, S.O., 2011. Corticotropin-releasing factor neurogenesis during midlife development in salmon: genetic environmental and thyroid hormone regulation. J. Neuroendocrinol. 23, 733-741.

Edgar, R., Domrachev, M., Lash, A.E., 2002. Gene Expression Omnibus: NCBI gene expression and hybridization array data repository. Nucleic Acids Res. 30, 207-210.

Fowler, S.L., Hamilton, D., Currie, S., 2009. A comparison of the heat shock response in juvenile and adult rainbow trout (Oncorhynchus mykiss) - implications for increased thermal sensitivity with age. Can. J. Fish. Aquat. Sci. 66, 91-100.

Guiry, A., Flynn, D., Hubert, S., O'Keeffe, A.M., LeProvost, O., White, S.L., Forde, P.F., Davoren, P., Houeix, B., Smith, T.J., Cotter, D., Wilkins, N.P., Cairns, M.T., 2010. Testes and brain gene expression in precocious male and adult maturing Atlantic salmon (Salmo salar). BMC Genomics 11 (Article No.: 211).

Hardiman, G., Gannon, F., 1996. Differential transferrin gene expression in Atlantic salmon (Salmo salar L.) freshwater parr and seawater smolts. J. Appl. Ichthyol. 12, 43-47.

Infante, C., Ponce, M., Manchado, M., 2011. Duplication of calsequestrin genes in teleosts: molecular characterization in the Senegalese sole (Solea senegalensis). Comp. Biochem. Physiol. B 158, 304-314.

Ingerslev, H.C., Cunningham, C., Wergeland, H.I., 2006. Cloning and expression of TNF-alpha, IL-1 beta and COX-2 in an anadromous and landlocked strain of Atlantic salmon (Salmo salar L.) during the smolting period. Fish Shellfish Immunol. 20, 450-461.

Larsen, D.A., Swanson, P., Dickhoff, W.W., 2011. The pituitary-thyroid axis during the parrsmolt transformation of coho salmon, Oncorhynchus kisutch: quantification of TSH beta mRNA, TSH, and thyroid hormones. Gen. Comp. Endocrinol. 171, 367-372.

Marshall, W.S., Bryson, S.E., Midelfart, A., Hamilton, W.F., 1995. Low-conductance anion channel activated by cAMP in teleost $\mathrm{Cl}-$-secreting cells. Am. J. Physiol. 268, R963-R969.

McCormick, S.D., 1993. Methods for nonlethal gill biopsy and measurement of $\mathrm{Na}+, \mathrm{K}+$ ATPase activity. Can. J. Fish. Aquat. Sci. 50, 656-658.

McCormick, S.D., Bjornsson, B.T., Sheridan, M., Eilertson, C., Carey, J.B., Odea, M., 1995. Increased daylength stimulates plasma growth-hormone and gill $\mathrm{Na}+, \mathrm{K}+$ ATPase in Atlantic Salmon (Salmo salar). J. Comp. Physiol. B 165, 245-254.

McCormick, S.D., Hansen, L.P., Quinn, T.P., Saunders, R.L., 1998. Movement, migration, and smolting of Atlantic salmon (Salmo salar). Can. J. Fish. Aquat. Sci. 55, 77-92.

McCormick, S.D., Saunders, R.L., 1987. Preparatory physiological adaptations for marine life of salmonids: osmoregulation, growth, and metabolism. Am. Fish. Soc. Symp. 1, 211-229.

McCormick, S.D., Shrimpton, J.M., Moriyama, S., Bjornsson, B.T., 2007. Differential hormonal responses of Atlantic salmon parr and smolt to increased daylength: a possible developmental basis for smolting. Aquaculture 273, 337-344.

Munro, C., Stabenfeldt, G., 1984. Development of a microtitre plate enzyme immunoassay for the determination of progesterone. J. Endocrinol. 101, 41-49.

Nilsen, T.O., Ebbesson, L.O.E., Madsen, S.S., McCormick, S.D., Andersson, E., Bjornsson, B.T., Prunet, P., Stefansson, S.O., 2007. Differential expression of gill $\mathrm{Na}+$, $\mathrm{K}+-$ ATPase alpha- and beta-subunits, $\mathrm{Na}+, \mathrm{K}+, 2 \mathrm{Cl}(-)$ cotransporter and CFTR anion channel in juvenile anadromous and landlocked Atlantic salmon Salmo salar. J. Exp. Biol. 210, 2885-2896.

Olsvik, P.A., Lie, K.K., Jordal, A.E., Nilsen, T.O., Hordvik, I., 2005. Evaluation of potential reference genes in real-time RT-PCR studies of Atlantic salmon. BMC Mol. Biol. 6, 21.

O'Keeffe, A.M., Hubert, S., Voisin, M., Houeix, B., Cotter, D., Cairns, M.T., 2008. Somatolactin mRNA expression during the parr-smolt transformation in hatchery-reared Atlantic salmon Salmo salar smolts. J. Fish Biol. 73, 436-443.

Okuzawa, K., Amano, M., Kobayashi, M., Aida, K., Hanyu, I., Hasegawa, Y., Miyamoto, K., 1990. Differences in salmon GNRH and chicken GNRH-II contents in discrete brainareas of male and female rainbow trout according to age and stage of maturity. Gen. Comp. Endocrinol. 80, 116-126.

Ou, Y.H., Chung, P.H., Hsu, F.F., Sun, T.P., Chang, W.Y., Shieh, S.Y., 2007. The candidate tumor suppressor BTG3 is a transcriptional target of p53 that inhibits E2F1. EMBO J. 26, 3968-3980.

Pan, F., Zarate, J., Choudhury, A., Rupprecht, R., Bradley, T.M., 2004. Osmotic stress of salmon stimulates upregulation of a cold inducible RNA binding protein (CIRP) similar to that of mammals and amphibians. Biochimie 86, 451-461.

Protasi, F., Paolini, C., Dainese, M., 2009. Calsequestrin-1: a new candidate gene for malignant hyperthermia and exertional/environmental heat stroke. J. Physiol. 587, 3095-3100.

Purcell, M.K., Nichols, K.M., Winton, J.R., Kurath, G., Thorgaard, G.H., Wheeler, P., Hansen, J.D., Herwig, R.P., Park, L.K., 2006. Comprehensive gene expression profiling following DNA vaccination of rainbow trout against infectious hematopoietic necrosis virus. Mol. Immunol. 43, 2089-2106.

Rajeevan, M.S., Vernon, S.D., Taysavang, N., Unger, E.R., 2001. Validation of array-based gene expression profiles by real-time (kinetic) RT-PCR. J. Mol. Diagn. 3, 26-31.

Rise, M.L., Jones, S.R.M., Brown, G.D., von Schalburg, K.R., Davidson, W.S., Koop, B.F., 2004a. Microarray analyses identify molecular biomarkers of Atlantic salmon macrophage and hematopoietic kidney response to Piscirickettsia salmonis infection. Physiol. Genomics 20, 21-35.

Rise, M.L., von Schalburg, K.R., Brown, G.D., Mawer, M.A., Devlin, R.H., Kuipers, N., Busby, M., Beetz-Sargent, M., Alberto, R., Gibbs, A.R., Hunt, P., Shukin, R., Zeznik, J.A., Nelson, C., Jones, S.R.M., Smailus, D.E., Jones, S.J.M., Schein, J.E., Marra, M.A., Butterfield, Y.S.N., Stott, J.M., Ng, S.H.S., Davidson, W.S., Koop, B.F., 2004b. Development and application of a salmonid EST database and cDNA microarray: data mining and interspecific hybridization characteristics. Genome Res. 14, 478-490.

Saeed, A.I., Sharov, V., White, J., Li, J., Liang, W., Bhagabati, N., Braisted, J., Klapa, M., Currier, T., Thiagarajan, M., Sturn, A., Snuffin, M., Rezantsev, A., Popov, D., Ryltsov, A., Kostukovich, E., Borisovsky, I., Liu, Z., Vinsavich, A., Trush, V., Quackenbush, J., 2003. 
TM4: a free, open-source system for microarray data management and analysis. Biotechniques 34, 374-378.

Sakamoto, T., Hirano, T., Madsen, S.S., Nishioka, R.S., Bern, H.A., 1995. Insulin-like growth factor I gene expression during parr-smolt transformation of coho salmon. Zool. Sci. 12, 249-252.

Schroeder, A., Mueller, O., Stocker, S., Salowsky, R., Leiber, M., Gassmann, M., Lightfoot, S., Menzel, W., Granzow, M., Ragg, T., 2006. The RIN: an RNA integrity number for assigning integrity values to RNA measurements. BMC Mol. Biol. 7 (Article No.: 3). Seear, P.J., Carmichael, S.N., Talbot, R., Taggart, J.B., Bron, J.E., Sweeney, G.E., 2010. Differential gene expression during smoltification of Atlantic salmon (Salmo salar L.): a first large-scale microarray study. Mar. Biotechnol. 12, 126-140.

Seidelin, M., Madsen, S.S., Cutler, C.P., Cramb, G., 2001. Expression of gill vacuolar-type $\mathrm{H}+-$ ATPase $\mathrm{B}$ subunit, and $\mathrm{Na}+, \mathrm{K}+-$ ATPase alpha1 and beta1 subunit messenger RNAs in smolting Salmo salar. Zoolog. Sci. 18, 315-324.

Sheridan, M.A., 1989. Alterations in lipid-metabolism accompanying smoltification and seawater adaptation of salmonid fish. Aquaculture 82, 191-203.

Siebzehnrubl, F.A., Buslei, R., Eyupoglu, I.Y., Seufert, S., Hahnen, E., Blumcke, I., 2007. Histone deacetylase inhibitors increase neuronal differentiation in adult forebrain precursor cells. Exp. Brain Res. 176, 672-678.

Singer, T.D., Clements, K.M., Semple, J.W., Schulte, P.M., Bystriansky, J.S., Finstad, B. Fleming, I.A., McKinley, R.S., 2002. Seawater tolerance and gene expression in two strains of Atlantic salmon smolts. Can. J. Fish. Aquat. Sci. 59, 125-135.

Specker, J.L., Schreck, C.B., 1984. Thyroidal response to mammalian thyrotropin during smoltification of coho salmon (Oncorhynchus kisutch). Comp. Biochem. Physiol. A $78,441-444$.
Storey, J.D. Tibshirani, R., 2003. Statistical significance for genomewide studies. Proc. Natl. Acad. Sci. U. S. A. 100, 9440-9445

Sullivan, C.V., Dickhoff, W.W., Mahnken, C.V.W., Hershberger, W.K., 1985. Changes in the hemoglobin system of the Coho Salmon Oncorhynchus kisutch during smoltification and triiodothyronine and propylthiouracil treatment. Comp. Biochem. Physiol. A 81, 807-813.

Towle, D.W., Henry, R.P., Terwilliger, N.B., 2011. Microarray-detected changes in gene expression in gills of green crabs (Carcinus maenas) upon dilution of environmental salinity. Comp. Biochem. Physiol. D 6, 115-125.

von Schalburg, K.R., McCarthy, S.P., Rise, M.L., Hutson, J.C., Davidson, W.S., Koop, B.F., 2006 Expression of morphogenic genes in mature ovarian and testicular tissues: potential stem-cell niche markers and patterning factors. Mol. Reprod. Dev. 73, 142-152.

von Schalburg, K.R., Rise, M.L., Brown, G.D., Davidson, W.S., Koop, B.F., 2005a. A comprehensive survey of the genes involved in maturation and development of the rainbow trout ovary. Biol. Reprod. 72, 687-699.

von Schalburg, K.R., Rise, M.L., Cooper, G.A., Brown, G.D., Gibbs, A.R., Nelson, C.C. Davidson, W.S., Koop, B.F., 2005b. Fish and chips: Various methodologies demonstrate utility of a 16,006-gene salmonid microarray. BMC Genomics 6 (Article No.: 126).

Yada, T., Kobayashi, T., Urano, A., Hirano, T., 1992. Changes in growth hormone and prolactin messenger ribonucleic acid levels during seawater adaptation of amago salmon Oncorhynchus rhodurus. J. Exp. Zool. 262, 420-425. 